REVIEWS

\title{
Selenium and yeast: Genetic mechanisms of the yeast tolerance to selenium compounds and their analogs
}

\author{
M. M. Stenchuk', L. B. Chaban ${ }^{1,2}$, M. V. Gonchar ${ }^{1,2}$ \\ ${ }^{1}$ Institute of Cell Biology, NAS of Ukrain \\ 14/16, Dragomanov Str., 79005 Lviv, Ukraine \\ ${ }^{2}$ Ivan Franko National University of Lviv \\ 4, Hrushevskyi Str., 79005 Lviv, Ukraine \\ gonchar@biochem.lviv.ua
}

\begin{abstract}
Selenium ( $\mathrm{Se}$ ) and its compounds have toxic and carcinogenic effect on animal and human beings, but in small concentrations this microelement is essential for life. Therefore, it is important to establish the molecular basis of Se toxicity and cell resistance to this element. Many investigations of this problem have been carried out on bacteria. Genetic approaches, available for the yeasts, made these eukaryotic microorganisms, especially S. cerevisiae, a convenient model for the investigation of molecular mechanisms of Se tolerance. This review summarizes the knowledge of genetic mechanisms involved in Se tolerance in yeasts.
\end{abstract}

Key words: yeast, selenium, tolerance.

Introduction. Selenium is a vitally important microelement for most organisms - from bacteria and algae to mammals. Though it was discovered by J.J. Bercelius in 1817, it was recognized as an important microelement only in 1957, and before the toxicity of this element was the main subject of researches. The study of selenium role in biology, medicine and veterinary may be a vivid example of tight connection of basic and applied science. Selenium is an element of the $4^{\text {th }}$ group of Mendeleev's periodic system, therefore, it reveals non-metallic as well as metallic properties. It composes chemical compounds (inorganic and organic) analogous to sulfur compounds, namely selenite $\left(\mathrm{SeO}_{3}{ }^{2-}\right)$, selenate $\left(\mathrm{SeO}_{4}^{2-}\right), \quad$ selenides, selenomethionine, selenocysteine, etc. The main source of selenium for humans and animals is the plants that assimilate this element depending on its concentration, availability, forms of selenium in the ground, and plant variety. The most stable

(C)

M. M. STENCHUK, L. B. CHABAN, M. V. GONCHAR forms of selenium in the ground are selenite and selenate. The total amount of selenium in the ground has a broad range from 0.000005 to $1.2 \mathrm{~g} / \mathrm{kg}$. Such a broad range results in the negative consequences for organisms which are in the areas of ultimate concentrations - suffering from the lack of selenium as a microelement or from its excessive amount. Meanwhile the range of selenium concentrations from minimal requirements to lethal dose is very narrow. Thus, minimum fodder level for animals is about $0.05-0.10$ $\mathrm{mg} / \mathrm{kg}$ of dry fodder, while $2-5 \mathrm{mg} / \mathrm{kg}$ is toxic already [1]. Admissible concentrations of selenium in food products for a human are considered to be $0.1-1.0 \mathrm{mg} / \mathrm{kg}$, and recommended selenium dose for preventive treatment is 5 $\mathrm{Mg} / \mathrm{kg}$ of human weight [2]. A narrow range between useful and harmful levels complicates preventive treatment and therapeutic usage of selenocompounds for humans and animals, so further researches of sensitivity/resistance mechanisms of organisms to selenium compounds are worth considering. 
Selenium and its compounds are used in electronic industry at production of copying equipment and photoelements, and in building industry at production of glass architecture blocks, coloring agents within plastic and paints, so there is an urgent question of bioremediation of environment polluted by selenium, using yeast and other microorganisms in particular, which obviously should have maximum resistance to the toxic action of selenium. The problem of tolerance arises also while using such metalloid-containing poisons as fungicides and insecticides, because pests and parasites often show undesired high resistance to metalloids which prohibits effective processing [3, 4].

Inorganic selenium can be assimilated by all kinds of organisms though the effectiveness of compounds bioutilization depends on their chemical nature and kind of organisms. Thus, assimilation of selenate which is the main source of selenium in the ground occurs in plants as well as in yeasts through the pathway of sulfate reduction, as corresponding enzymes do not discriminate sulfur and selenium: selenate ч adenosyl-phosphoselenate $ч$ adenosine-3-phospho-5-phosphoselenate ч selenite ч selenide ч selenocysteine (SeCys) ч selenomethionine (SeMet). In Archea and Eubacteria (probably, not in all of them) and in animals (invertebrate and vertebrate) selenium can be included into polypeptide chains as so called twenty first amino acid SeCys [5]. Thus, the synthesis of these proteins which are usually called selenoproteins should include selenospecific mechanisms which would differentiate between selenium and sulfur. UGA is the codon which provides SeCys binding, and which functions as nonsense-codon in other conditions (at the end of a gene). This way of selenocysteine inclusion is specific - Se becomes the component of active centers of a number of selenoproteins, for instance, bacterial formate dehydrogenases, eukaryotic glutathione peroxidases and thioredoxin reductases functioning as catalytically active heteroatom. During several decades after the discovery of selenium as an important microelement, more than 20 eukaryotic and 15 prokaryotic selenoproteins containing twenty first amino acid selenocysteine were identified. The majority of these proteins participate in redox-reactions through selenocysteine which acts as an important component of the catalytic cycle. They play an important role in the metabolism of malignant tumors, in the control of cell division, oxygen metabolism, detoxification processes, apoptosis induction, immune system functioning etc. Selenoproteins have not been discovered in yeasts and higher plants $[6,7]$.

The second way of selenium incorporation in proteins is not specific - it can substitute sulfur with the formation of free amino acids of selenocysteine and selenomethionine which are included non-specifically into proteins instead of cysteine and methionine, respectively. Such proteins are not called selenoproteins. With the usage of bacteria as model systems it was shown that the effect of substituting methionine and cysteine for their selenium derivatives depended on the number of substitutions and their location in polypeptide - they can either increase or decrease its function even to zero, or not influence it [8-10]. This way functions at all the levels of living systems, in yeasts, in particular, irrespective of the presence of synthesis mechanisms of selenoproteins in them.

Due to its antioxidant properties selenium supplement to the diet in certain concentration protects human organism from cardiovascular diseases, viral infections, rheumatoid arthritis, liver diseases and some forms of cancer. The presence of selenium in fodder in optimum concentrations results in decrease of tumors occurrence frequency in experimental animals. Many years of the research in the USA on 1300 patients showed that consumption of selenium for 6 years in the amount of $200 \mathrm{Mg}$ per day in the form of Se-enriched yeast biomass decreased total frequency of malignant tumors by $50 \%$ [11]. Its deficiency in food products and fodder for animals results in a number of diseases (in humans - Keshan syndrome (cardiomiopathy), Kashin-Beck (chondronecrosis)) etc. Epidemiologic study in the USA showed the correlation between low amount of selenium in food products and increased frequency of some kinds of tumors in humans [11].

Yeast as a model organism in the study of assimilation and toxicity of selenium compounds. The role of selenium in biology, medicine and veterinary is described more substantially in the reviews $[1,5,6,11,12]$, where it mainly goes about bacteria, plants and higher eukaryotes. The aim of this review is to summarize the results of the study of selenium compounds influence on the yeast cells. These microorganisms are one of the most studied eukaryotic cells which have a number of fundamental properties common with the mammalian cells. This allows using them to study metabolic processes which are not studied yet or enough in lower, as well as in higher eukaryotes. In this review we concentrated on the main concepts of physiology and biochemistry of selenium in yeasts, mainly in Saccharomyces cerevisiae, including selenium consumption and transport as well as mechanisms of selenium toxicity and yeast tolerance to it.

As it was already stated, that selenium metabolism in yeast does not include selenoproteins synthesis. Full sequencing of the yeast genome did not reveal intragenic opal codons UGA, located in an open frame sequences with AUG [5]. It should be noted that it concerns only 
Saccharomyces. Selenium metabolism in non-conventional yeasts has not been studied until present, so it is possible that yeast selenoproteins would be revealed at further study of numerous genera and species of these microorganisms. Even recently, it was considered that plants do not have selenoproteins either. This fact would mean that either they lost the corresponding mechanism in the course of evolution or insufficient amount of material was studied. Evidently, the latter is true, as recently it has been proved that in a representative of the vegetable kingdom Chlamidomonas reinhardtii glutathione peroxidase contains selenocysteine, the inclusion of which into polypeptide occurs due to UGA codon [13].

The study of 404 yeast strains which belong to 40 genera showed that their sensitivity/resistance to selenate varies widely. The growth of some strains can be suppressed by selenium even at the concentration of $0.1 \mathrm{mM}$, while some others grow in the presence of $100 \mathrm{mM}$. Generally, ascomycetes are more tolerant to selenium, than basidiomycetic fungi. The chemical composition of the media, in particular, the content of sulfate and sulfur-containing amino acids, influences the sensitivity to this element [14].

A considerable part of experimental works, dedicated to the study of selenium influence on yeast, was performed using selenate as its source. It was shown that this analogue of sulfate influences the growth of $S$. cerevisiae depending on its concentration. At the presence of 1-5 $\mathrm{mM}$ selenate in a medium, the exponential growth of a culture slows down, and its transition to the stationary phase occurs at a smaller cells' concentration. Life cycle of $60 \%$ of cells treated with selenate $(5 \mathrm{mM})$ is stopped at the budding stage, though the smaller part finishes their division with the separation of doughter cells, which may testify the adaptation of a part of the culture to the toxic action of selenite. Selenite has also lethal action on cells of $S$. cerevisiae depending on its concentration in a medium. Evidently, a negative influence of selenite on the growth of yeast culture occurs mainly due to suppression of mitosis as well as its lethal action on cells [15]. Non-conventional flavinogenic yeast Pichia guilliermondii is more sensitive to selenite than $S$. cerevisiae - its growth in a synthetic medium is almost completely blocked at its concentration of $0.5-1.0 \mathrm{mM}$ [16]. Mammalian cells are even more sensitive - selenite is extremely toxic for them even in micromolar concentrations [17]. Probably, one of the reasons of different sensitivity of cells to selenite is their different capacity to detoxicate it. The cells of Escherichia coli neutralize toxic selenite by its reduction to elementary selenium $\left(\mathrm{Se}^{\circ}\right)$ [18]. The process of reduction leads to the appearance of spe- cific red color of culture and to the formation of $\mathrm{H}_{2} \mathrm{O}_{2}$ and $\mathrm{O}_{2}^{-}$, which are considered [19] to cause the toxicity of selenite in Salmonella typhimurium. The culture of $S$. cerevisiae

Table 1

Content (\%) of inorganic and organic selenocompounds in the yeast biomass (total selenium content $-1922 \mathrm{mg} / \mathrm{kg}$ of dry biomass) [28].

\begin{tabular}{lc}
\hline \multicolumn{1}{c|}{ Compound } & $\%$ \\
\hline Selenate & Not detected \\
Selenite & 1 \\
Selenocystine & 0.5 \\
Selenocystathionine & 1 \\
Se-methylselenocysteine & 0.5 \\
?-Glutamyl-Se-methylcysteine & 0.5 \\
Selenomethionine & 85 \\
Se-adenosylselenohomocysteine & 3 \\
Selenolanthionine & 1.5 \\
Total selenium & 93 \\
\hline
\end{tabular}

also reddens during cultivation in a medium with selenite because of the accumulation of red substance in vacuoles, which, in the authors' opinion [15], is elementary selenium $\left(\mathrm{Se}^{\circ}\right)$. It was shown that at cultivating yeast Candida tropicalis in a medium with selenium $\left(\mathrm{SeO}_{2}\right)$ the granules of free selenium accumulate in their vacuoles as well [20,21].

The study of mutants, avoid of vacuoles as well as defective in vacuolar $\mathrm{H}^{+}$-ATPase, also evidences an important role of $S$. cerevisiae vacuole in selenium detoxication. All three tested strains revealed an increased sensitivity to the tellurite and chromate, because of oxyanions accumulation in the cytosol. Evidently, their detoxification needs intact vacuole which participates in metalloid compartmentalization, as well as in regulation of cytosolic detoxification processes, i.e. reduction. Vice versa, the mutants accumulated less selenium and were more tolerant to selenite than parent strain. According to the authors of [22] this result shows that selenium accumulation occurs mainly in vacuole and the activity of $\mathrm{V}-\mathrm{H}^{+}$-ATPase may be involved in this process.

The collection of selenite-resistant $\left(\mathrm{Sit}^{\mathrm{r}}\right)$ mutants of the yeast $P$. guilliermondii was isolated, and the characteristic feature of them, contrary to the parent strain, was quick change of their biomass color from white to red during the growth in a medium supplemented with comparatively low concentrations of selenite [23]. The cells of the wild strain can also change its color, but only to pink and only after 
long-term ( $>7$ days) cultivation in the presence of sublethal concentration of selenite. The previous characterization of the selenite-induced stained substance isolated from the mutant cells of $P$. guilliermondii evidences the formation of a red form of $\mathrm{Se}^{\circ}$ in them. These data indirectly approve the existence of the reductive pathway of selenite detoxification in yeast [23], but formation of elemental $\mathrm{Se}^{\circ}$ in the cells should be confirmed also by direct chemical identification.

Selenium and sulfur have very similar physico-chemical properties, which allow consumption and assimilation of selenium through the metabolic way for sulfur. Organic compounds of selenium and selenium-containing amino

Table 2

Anticancerogenic efficiency of different selenium compounds for suppression of mammary tumors in rats [39]

\begin{tabular}{l|c}
\hline \multicolumn{1}{c|}{ Component } & $\begin{array}{c}\text { Selenium dose (ppm) for } \\
50 \% \text { suppression }\end{array}$ \\
\hline Seleno-methyl-selenocysteine & 2 \\
Selenobethaine & 2 \\
Methyl ether of selenobethaine & $2-3$ \\
Selenite & 3 \\
Selenomethionine & $4-5$ \\
Selenocysteine & $4-5$ \\
\hline
\end{tabular}

acids (bioselenium preparations) are considered to be the most favorable sources of Se for humans and animals. At corresponding conditions yeast can accumulate selenium and include it into these compounds. At cultivating in a medium with selenite at certain conditions about $60 \%$ of organic selenium is located in structural compartments of the yeast, namely, in the fraction of microsome membranes, endoplasmic reticulum, Goldgi-vacuoles and other organelles. Mitochondria also contain a considerable amount of organic selenium. "Org-selenium" was found in peptides, where selenium substitutes for sulfur, in lipid fractions (membranous and non-membranous), glycoprotein fractions of cellular walls and in structural components of the yeast surface. There is still no definite answer to the question, whether the efficacy of this complicated biological system depends on the substitution of sulfur with selenium. Probably, as in the case of enzymes in bacteria, the effect will depend on the amount and location of substitutions.

As for quantitative ratio of different selenium compounds in the biomass of "selenized" yeast, it depends on the conditions of the yeast cultivation. It is possible to produce the baker's yeast of a high quality enriched with selenium at conditions providing a specific rate of its assimilation near $40-50 \mathrm{mg} \cdot \mathrm{g}^{-1} \cdot$ hour $^{-1}$. The content of undesired inorganic selenium in cells can be decreased to $5-6 \%$, though the biomass yield will be $20 \%$ less [24, 25]. At corresponding conditions $\left(\mathrm{pH}, \mathrm{t}^{\circ}\right.$, airation, selenium content in a medium, etc) the $S$. cerevisiae cells can accumulate selenium up to $1000-2000 \mathrm{Mg} / \mathrm{g}$ of dry biomass, and more than $80 \%$ of selenium can be in the form of SeMet (Table 1). For the optimization of the yeast cultivation it is profitable to use processes of continuous fermentation [26, 271.

SeMet is considered less toxic for organisms than inorganic compounds of selenium [1]. However, this conclusion seems to concern not all the kinds of organisms. Thus, a comparative study of the influence of two selenium compounds, organic (selenomethionine) and inorganic (selenite), on the growth, viability and antioxidant status of $S$. cerevisiae cells showed that both forms of selenium at increasing concentration in a medium decreased proportionally the cells viability and their quantity in a culture, though selenium content was increased in cells, and the effect of selenomethionine was stronger [29].

Yeasts as the source of selenium for animals and humans Selenized yeasts are more assimilated and therefore they are a better source of selenium not only for humans but also for animals. Therefore, to estimate the availability of different forms of selenium the male rats (4 weeks age, experimental group) were fed for 4 weeks with fodder supplemented by selenium $(0.04,0.08,0.16$, and $0.32 \mathrm{Mg} / \mathrm{g})$ either in the form of selenite or as enriched yeast biomass ("SeY"). The control group was kept on non-selenium diet. Selenium did not influence the growth and biochemical tests of blood and serum. Its content and the activity of glutathione peroxidase in liver, serum, and erythrocytes increased gradually according to selenium added. At low selenium doses $(0.04$ and $0.08 \mathrm{Mg} / \mathrm{g})$, selenite provided a greater content of selenium and a higher activity of glutathione peroxidase when compared to $\mathrm{SeY}$, though at higher selenium level $(0.32 \mathrm{Mg} / \mathrm{g})$ these values were greater for SeY. It was shown that bioavailability of selenium as $\mathrm{SeY}$ in comparison with selenite $(100 \%)$ was higher in tissues - $135-165 \%$, as well as for glutathione peroxidase activity - 105-197\%, i.e. SeY is a better source of selenium for rats than selenite [30].

The concentration of selenium in liver of pigs, weighted about $24 \mathrm{~kg}$, which were fed for 9 weeks with selenized yeasts $(0.3 \mathrm{mg}$ selenium per $\mathrm{kg}$ ) was considerably higher than in the liver of those fed with the addition of selenite $(0.3 \mathrm{mg}$ of selenium per $\mathrm{kg}$ ) [31]. 
The investigation of ability of selenite, selenate, and $\mathrm{SeY}$ to increase the Se concentration in milk, serum and blood of cows showed that the enrichment of fodder with selenite and selenate had no significant influence on Se amount in milk, and there was no difference between the effects of these two selenium compounds. Instead, the action of organic selenium ( $\mathrm{SeY}$ ) (comparing to inorganic selenium) was 2 or 3 times more effective in the increase of selenium level in milk, blood, and serum [32-34].

Newborn lambs, the mothers of which were fed with $\mathrm{SeY}$, had a higher content of selenium and the activity of glutathione peroxidase in blood, than those the mothers of which were fed by selenite. The ewes fed with SeY had a higher quantity of selenium in foremilk in comparison with nourishing with selenite. Thus, selenium of SeY passed easier into foremilk and foetuses of lambing ewes than in form of selenite.

Though the need of humans and animals for selenium is well-founded, still the question about its form for consumption is under consideration. Preferably, the selenium should be consumed in the form which is found in natural products. As the natural products contain selenium mainly as L-isomer of selenomethionine (SeMet), the synthetic L-SeMet or food enriched by it can be used as additional forms of selenium for humans. It is important not only for adults but also for children. It is shown, for example, that bioavailability of selenium in the form of SeY for premature infants is higher than other selenium compounds. Children whose parents lived in the area of Hungary, deficient in selenium, received $4.8 \mathrm{mg} \mathrm{SeY} \mathrm{(5} \mathrm{mg}$ of Se) every day during first 14 days after birth. The authors did not found any complications or side effects after giving children the preparation of $\mathrm{SeY}[36,37]$. Still the question arises which has no a grounded answer yet - how biologically active are other numerous compounds of selenium (organic and inorganic)? Probably it is advantageous to use not only SeMet, but also other selenium compounds for different aethiologies. Selenium is known to reveal a number of antitumor effects but only some of them depend on glutathione peroxidase, which protects DNA from the actions of mutagens, and on regulatory protein p53 (tumor suppressor) which controls DNA reparation and the activity of which can be increased by SeMet as an anticancerogenic factor in this case [38].

It is still not known whether there are any other mechanisms of selenium antitumor action. Evidently, they exist, as it was shown in the experiments on higher eukaryotes that selenocompounds can significantly differ by their mode of influencing a cell [39-41]. For example, it was shown that not selenomethionine and selenocysteine, but other selenium compounds (inorganic selenite, in particu- lar) can be more effective in preventing tumors in rats (Table 2). It is worth mentioning that selenomethylselenocysteine which was one of the effective components in this experiment, as well as SeMet, is synthesized by yeast cells and maybe it is possible to select yeast strains, the biomass of which would be enriched with this component and not SeMet (and, probably with both).

This problem is important also because there are data about the presence of some factors (derivatives of selenium metabolism?) in food and fodder, enriched by selenium, which mediate selenium action in cancer aethiology (probably, in other aethiologies as well). There are antagonists of selenium among them which suppress the antitumor action not only of selenium but also of other antioxidants ascorbic acid, retinol, B-carotin, б-tocopherol, that synergistically interact as antitumor preparations [42].

Genotoxic and mutagenic potential of selenium. It is known that selenium reveals two effects in the cells of mammalian cells: in the nanomolar range it stimulates cells growth, while micromolar concentrations are extremely toxic [17]. It also has a dual effect on yeast: at ten-fold higher concentrations (in the micromolar range) suppresses spontaneous mutagenesis, but becomes toxic, genotoxic in particular, at milimolar concentrations. Selenite in the concentration of 1-15 mmoles/plate suppressed spontaneous mutagenesis completely in two independent loci his 1-7 (missense mutation) and lys 1-1 (amber mutation) of $S$. cerevisiae [43]. The degree of suppression depended on selenite concentration, strain and locus. 30-times higher selenite concentration was necessary to suppress the frequency of spontaneous reversions in the histidine locus, in comparison with the lysine locus. Both loci reacted differently to two other inorganic selenium derivatives. Spontaneous mutagenesis in the lysine locus was suppressed completely by selenite in the concentration of 3 mmoles/plate while the histidine reversions were suppressed only at 30 mmoles. Selenate suppressed reversions in the lysine but not in the histidine locus. These results show that exogenous additives (in this case selenium compounds) can influence considerably genetically controlled readiness of the organism to respond to mutagenesis and they prove the complexity of such interactions. The mechanisms of suppressing the frequency of spontaneous mutations by selenium in yeast are not known. Probably, the selenium compounds act as antioxidants, decreasing a pool of mutagenic free radicals.

At higher concentration (1-10 $\mathrm{mM})$ selenium acts as a mutagen, revealing toxicity as well. In $S$. cerevisiae it induces direct mutations in the CAN1 locus, which codes arginine permease. The mutants can $^{r}$ are resistant to canavanine and their registration can be easily performed 
in the medium with this toxic analogue of arginine. Their frequency under the treatment of cells with a high concentration of selenite $(10 \mathrm{mM})$ increased 6 times and amounted to about $80 \cdot 10^{-6}[15]$. The frequency of these direct mutations was close to the frequency of back mutations, induced by selenite [44].

In diploid strains of $S$. cerevisiae selenite, besides toxicity manifestation, revealed recombinogenic and mutagenic effects: it induced gene conversion, mitotic crossing-over, back mutations and appearance of aberrant colonies [44]. Interestingly that selenomethionine, as well as selenite, has mutagenic and antimutagenic effects in haploid strains of S. cerevisiae - depending on the concentration, and the latter is observed in both stationary and logarithmic phases of the growth. The authors used hydrogen peroxide as a mutagen. The activity of catalase, superoxide dismutase and glutathione peroxidase was much higher in the presence of both selenium compounds [45].

The mechanisms of selenite action as a mutagenic factor. As selenite influences negatively the growth of $S$. cerevisiae by blocking mitosis, it was supposed [15] that this action was caused by DNA damage, the reparation of which demands prior delay in mitosis and which is known to be controlled by the $R A D 9$ gene. Indeed, a mutant rad 9 was shown to be more sensitive to selenite than the wild type strain. The conclusion was made that delay in mitosis under the $R A D 9$ control is necessary for the reparation of DNA damage, induced by selenite. To understand the nature of these damages, the sensitivity to selenite was determined for the mutants, defective in different ways of DNA reparation. Taking into consideration a possible oxidizing capacity of selenite, the sensitivity of strains defective in the reparation of DNA oxidative damages (the reparation by excision of bases) was first to study. None of the defective genes ogg 1, ntg 1, ntg2 and apn 1 influenced resistance to selenite considerably. Probably, the DNA damages caused by selenite are not repaired by the products of wild type alleles of these genes.

Mutations in the genes RAD51 and RAD52 which code for the components of reparation of the DNA double-strand breaks did not increase significantly the sensitivity to selenite, which, then, does not cause such DNA damage. A similar conclusion was made concerning $R A D 1$, which participates in the DNA reparation by excision of nucleotides. At last, it was revealed that only one of four known ways of the DNA reparation participates in the elimination of DNA damages, induced by selenite - the one where DNA-polymerase ж takes place [15]. Mutations in the $R E V 3$ gene which codes for this enzyme, increased considerably the sensitivity of cells to selenite. This repara- tion type is mutagenic, as the enzyme directs replication of DNA on a damaged (probably by selenite) coding strand of DNA during which a probability of inclusion into newly synthesized strand of non-complementary nucleotide is increased, which may be the cause of mutations in this site. As the reparation of DNA, damaged by selenite, occurs not by excision of bases but with the participation of the REV 3 gene, the authors came to a conclusion that selenite generates in DNA not oxidized bases, but large adducts, which can be avoided only by DNA-polymerase ж [15].

It is not improbable that some of genotoxic selenite effects can be caused by hydrogen peroxide, which is produced due to the reaction of selenite with glutathione [19]. Selenite induces one-strand splits of DNA in the cells of mammary tumors of mice [40].

Mutants resistant to selenate and chromate. The effective approach for revealing genes which determine sensitivity/resistance of cells to some factors is the isolation of mutant cells with a changed tolerance to these factors, the genetic analysis of which in the combination with other methods allows revealing specific reasons of their resistance to the factors under study. In the work [46] the authors used selenate and chromate as selective factors to obtain cells, resistant to these toxic analogues of sulphur. It was known [47], that the selection of strains, resistant to chromate and selenate, mainly results in the isolation of mutants, which are defective in the MET3 gene (which codes for ATP-sulfurylase). To avoid this, the strain which had additional copies of the MET3 gene on a multy-copies plasmid, was used as the initial one. The cells of $S$. cerevisiae, treated with ethylmethansulfonate, were plated on synthetic medium which contained selenate $(2 \mathrm{mM})$ or chromate $(0.1 \mathrm{mM})$ or both compounds simultaneously at the same concentrations.

10 out of 39 selected resistant mutants were methinine-independent (phenotype $\mathrm{Met}^{+}$) and $29-$ methinine auxotrophes (Met'). The results of the complementary analysis showed that each of $24 \mathrm{Met}^{-}$-strains contained one of already known alleles met 1 , met 4 , met 14 or met 16. One of the strains contained two mutations - met 22 (already known) and sul3 (allele of a new gene SUL3). 4 other Met-strains contained mutant alleles of a new gene MET28 which codes for an activator of transcription.

Four most resistant strains were selected out of 10 methionine-independent strains for further analysis and it was shown that two of them carried one allele of new genes $S U L 3$ or SUL2, and two others were double mutants: one genes SUL2 and SUL1 (already known), and the other genes SUL1 and MET14. Mutations in gene SUL3 are dominant. It is noteworthy that there was no relationship found between the quantity and the classes of above men- 
tioned mutants and the types of selective media - with selenate, chromate or their mixture.

The rate of sulfate consumption by cells of the tested strains (nmoles $\cdot \mathrm{min}^{-1} \cdot \mathrm{mg}^{-1}$ of dry biomass) was for: wild type - 5.9; sul1 - 4.4; sul2 - 3.4; sul3 - 2.9; sul1 sul2 - < 0.1 ; sul1 sul3 $-<0.1$; sul2 sul3 -2.3 . Thus, though in the single mutants the rate of sulfate consumption was not much lower than in the wild type, it was sufficient to identify them by resistance to sulphur analogues. Only the combination of two mutations - sul1 sul2 or sul1 sul3 in one genome resulted in considerable decrease in the efficacy of sulfate consumption by the cells of such strains they were not able to grow in a medium with $1 \mathrm{mM}$ sulfate like a wild type, but demanded it in the concentration of 30 mM.

These double mutants were shown to be convenient for the $S U L$ genes cloning, the results of which demonstrated that the gene $S U L 1$ is located on II chromosome and codes for a protein which contains 859 amino acid residues and has 11 potential transmembrane domains. Its structure is identical to the protein revealed by Smith [48]. The gene SUL2 is located on XII chromosome and codes for a protein which contains 893 amino acids and has 10 transmembrane domains. Both proteins are highly homologous (62\%).

The above mentioned results showed that yeast cells have two high-affinity sulfate transporters which are coded by the genes SUL1 and SUL2. The function of the gene SUL3 remained still undefined. The inability of double mutants sul1 sul 2 and sul 1 sul 3 to grow in a medium with 1 $\mathrm{mM}$ sulfate could mean that $S u l 3 p$ regulates the activity of $S u l 2 p$ or the expression of the gene $S U L 2$. The kinetic study of the genes $S U L 1$ and $S U L 2$ derepression in the wild type strain and the sul3 showed that Sul3p activates the transcription of the gene SUL2. A low level of the gene SUL2 transcription in the mutant sul3 explains why double mutants sul1 sul2 and sul1 sul 3 have the same phenotype. It is still not known whether $S$. cerevisiae have a low-affinity system of sulfate transport into the cell. The fact that the mutant sul1 sul2 grows in the medium with a high content of sulfate $(30 \mathrm{mM})$ indicates the probability of its existence. It is also not known why the mutant sull, isolated in the work [45], does not grow in a medium which contains less than $5 \mathrm{mM}$ sulfate. Probably, the initial strain was already the mutant sul2? One more problem is that the mutant sul3 has a higher resistance to selenate than the strain sul2, so it is not improbable that the gene SUL3 participates in the regulation of other genes which take part in the sulphur metabolism.

Selenate-anion turned out to be toxic for Schizosaccharomyces pombe as well, which gave a possibil- ity to isolate from this yeast selenate-resistant mutants, which could not utilise sulfate, so they demanded for their normal growth such sources of sulphur as sulfite, thiosulfate, cysteine or glutathione, but not methionine $[49,50]$.The mutants were transformed using the genome library of $S$. pombe and the gene, which complemented selenate resistance, was identified as the one which codes for the enzyme ATP-sulfurylase, which in S.cerevisiae is coded by the gene MET3. On the authors' opinion, the inability of the mutants to use methionine as the source of sulphur is caused by the absence of reverse way of transsulfurylatiton in this organism. The wild type strains can use methionine as a source of sulphur after its degradation with the formation of sulfate. The authors did not use the above mentioned method [46], which allows isolating other mutants, besides MET3, which are defective in sulfate assimilation.

Resistance/sensitivity to sulfite. The research of mechanisms of cells tolerance, yeast in particular, to sulfites is of theoretical and practical important. Sulfites are widely used for food conservation, so it is important to know the conditions under which their action on the microorganisms (inhibit - do not inhibit) will be effective. Sulfite-resistance is an important feature of the wine strains of $S$. cerevisiae, and understanding its basis and the factors influencing it, can provide better management of sulfite usage. Sulfite is potentially toxic but at the same time it is a normal metabolite of many animals, plants and microorganisms, so they should have detoxification mechanisms selective for this anion. It is important to know what are these mechanisms, and whether they are specific only for sulfite, or are more general and prevent the negative influence of other related metabolites as well (for example, selenium compounds, selenite first of all). Finally, there is not much known about the reasons of hypersensitivity of some people to sulfites added to food products and drinks. It can be expected that the study on the ways of sulfites metabolism in yeast will become an important contribution into solving this important problem as well. Though the sulfite metabolism in humans and yeast occurs in different ways, it is not improbable that cellular targets for sulfite (protein or other molecules) may be similar in these organisms. The results of complete sequencing of the human and $S$. cerevisiae genomes showed that much can be learned about the human features, studying analogous processes in the yeast.

At the beginning of the study of the yeasts the authors considered the following mechanisms of sulfite detoxification as possible though not exceptional: 1) the assimilation of sulfite trough increased formation of methionine and cysteine - the main final products of a normal sulfite-generating metabolic pathway of the yeast; 2) increased syn- 
thesis of sulfite-binding agents - for example, acetic aldehyde; 3 ) decreased consumption of sulfite. At the first stage of investigations, the sulfite-resistant and sulfite-sensitive variants or mutants were isolated, the growth of which would not be influenced by sulfite in the concentration which is toxic to a parent strain or vice versa is more toxic for the mutant than for a wild strain.

Gene $\boldsymbol{F Z F 1}$. The collection of sulfite-resistant mutants of $S$.cerevisiae was first obtained and characterized by a group of Italian scientists [51-53]. The characteristic features of mutants were increased intracellular content of glutathione, higher glutathione reductase activity, smaller concentration of extracellular glutathione and elevated amount of extracellular acetic aldehyde in the presence as well as in the absence of sulfite. The resistant strains had considerably smaller ability to accumulate sulfite. No difference has been found between resistant and sensitive strains in the sensitivity of their glyceraldehyde-3-phosphate dehydrogenase to sulfite or glutathione. It was shown that resistance of seven mutants was inherited as one dominant mutation and that all seven mutations are allelic, i.e. they are located in one gene, which in the authors' opinion is vital in defining sensitivity/resistance of $S$. cerevisiae to sulfite. The results of cloning and sequencing a gene showed that it is identical to already described gene $F Z F 1$ [54], which codes for a protein with 5 zinc fingers, three of which are located in tandem in $\mathrm{N}$-terminal part of the protein. It indicates the protein belongs to the class of transcriptional factors but the question of its role in the sulfite metabolism remains unknown.

Gene SSU1. New light on the mechanisms of sensitivity/resistance of yeast to sulfite was shed by the research on one more mutants' collection of $S$. cerevisiae, which included the strains of two types - sensitive and resistant to sulfite (1-2 mM) [55]. The genetic analysis showed that mutations increasing cells sensitivity to sulfite are recessive and located in 4 genes (SSU1, SSU2, SSU3, SSU4). None of the sensitive mutants was defective in biosynthesis of methionine or cysteine which excluded the loss of sulfite-reductase activity as a possible reason of sensitivity. All the mutants of the group did not reveal sensitivity or resistance to other tested antioxidants (reducing agents), besides sulfite: cysteine, ascorbate, dithiothreitole, nitrite, glutathione and thiosulfate.

Further research showed that SSU1 gene, the mutant alleles of which increase cells' sensitivity to sulfite, codes for protein of 458 amino acids, localized in the membrane with 10 potential transmembrane domains. The conclusion was made that SSU1 codes for the transporter which participates in extruding sulfite out of the cell, but not in its assimilation. The fact that zero-mutants on SSU1 gene ac- cumulated more sulfite in cells, testified in favour of this conclusion, and vice versa gene overexpression on multi-copies plasmid resulted in considerable decreasing its quantity in the cell in comparison with its wild counterpart. The rate of extruding sulfite out of cells was more intense in the case of SSU1 expression on multi-copied plasmid [56].

It was discovered that some dominant mutations in earlier identified gene $F Z F 1$ as compared to the wild type allele increase the transcription of SSU1 gene 8-fold, and SSU1 being multi-copied increases sulfite-resistance of cells 3-8-fold. The rate of extruding bound sulfite from cells of wild type, ssull and $f z f 1$ mutants or cells with active multi-copied $S S U 1$ did not differ noticeably. It is in accordance with the conclusion that the protein Ssulp keeps a low, non-toxic level of sulfite by removing solely its free form out of the cells. A site of the gene SSU1 promoter was identified to which the protein Fzflp binds in vitro and regulates positively its transcription [57]. The role of Fzflp as an activator of $S S U 1$ is proved by the fact that Fzflp suppresses sulfite sensitivity of different mutant classes but not ssu1. Thus, the overexpression of genes $F Z F 1$ or/and $S S U 1$ is one of the effective ways to increase the yeast tolerance to sulfite due to the increase of the Ssu Ip action as a "sulfite pump" [58].

Similar transporters, known as $M d r$ (multidrug resistance) or $P d r$ (pleiotropic $d$ rug resistance) are widely spread in living nature - from bacteria to humans [59], but Ssulp differs from them in structure and mode of action. Transporters Mdr, on the contrary to Ssulp, need ATP energy to take a wide spectrum of toxic substances out of a cell.

Can Ssu1p remove some other toxic compounds, besides sulfite, out of a cell? Polyfunctional abilities of this protein as a pump were demonstrated by the increase of the expression of the genes SSU1 and FZF1 18-fold and 5-fold, respectively, after treating the cells with alkylating compound - methyl methanesulphonate, which is known to damage nucleic acids and proteins [60]. It is still not known whether Ssulp can identify and take this super-mutagen out of the cell, but the very fact of activation of both genes expression by it deserves special attention. Evidently, Ssulp recognizes a toxic analogue of sulfite, selenite, as well, as the increase of yeast resistance to the latter under the condition of $S S U 1$ overexpression in cells was discovered [15, 57].

The mutant ssu 2 was shown to be an allele to already known gene GRR1 [56], involved in glucose metabolism and other functions [61]. The mutation $g r r 1$ is pleiotropic: it determines changing cells morphology, increased sensitivity to reducing agents dithiothreitole, nitrites and 
thiosulfate, decreases excretion of acetic aldehyde and decreases the content of reduced glutathione in cells. Two latter metabolites interact with sulfite and this could be the way of its detoxification, but the sensitivity to sulfite of independently obtained mutant with considerably decreased glutathione content was not decreased [55]. Probably, the grr 1 mutants grow slowly on glucose because of the defect in high-affinity system of its transport. Still the sensitivity of the mutant $\operatorname{grr} 1$ to sulfite is probably caused by this defect only partially, since it showed an increased sensitivity on other carbon sources as well (galactose, maltose, acetate, ethanol and glycerol). Besides, a suppressor $r g l l$ of the defect of glucose metabolism in the mutant grr 1 did not suppress its sensitivity to sulfite completely, though $F Z F 1$ gene on multi-copies plasmid suppressed the sulfite sensitivity completely $[55,56]$. Thereupon, the main reason of sulfite sensitivity of mutant cells rgll (ssu2) is considered a decreased pool of acetic aldehyde, the reaction of which with sulfite generates a non-toxic product hydroxyethanesulfonate. Thus, the formation of acetic aldehyde by the yeast is an important way of sulfite detoxification. In favour of this assumption is the above mentioned fact of the excretion by sulfite-resistant mutants $f_{z} f 1$ (all the mutations are dominant) of much higher amounts of acetic aldehyde in comparison with the wild type cells [52]. It is also known that exogenous sulfite induces excretion of this metabolite by the cells of the wild type $S$. cerevisiae and Saccharomycodes ludwigii [62].

The resistance mutations are revealed to be dominant and located in the same gene, labelled as $R S U$ [55], shown to be identical to the gene $F Z F 1[53,58]$. The difference between the mutants' tolerance to sulfite appeared to be small. Thus, the resistant mutant RSU1 endures 3 times higher concentration of sulfite than a wild type strain which is twice more tolerant to sulfite than the most sensitive mutants. The dominance of mutation FZF1-4 makes it convenient for the selection of industrial and laboratory strains of $S$. cerevisiae [58].

While studying molecular mechanisms of selenite detoxification by the yeast cells, the authors [15] searched for genes which being overexpressed would increase the resistance to selenite. The wild strain $S$. cerevisiae was transformed using a genome library on multi-copies plasmid. About 60000 transformants were transfered to a minimum medium, which contained $20 \mathrm{mM}$ selenite. Two plasmids were selected which provided increased resistance of cells to selenite, each of them carried a single gene - already known $S S U 1$, ensuring cells resistance due to the mutation [56], and GLR1 which codes for NADPH-dependent glutathione reductase. Overexpression of the latter, as well as the former, increased the selenite resistance of cells.
Overexpression of both genes (SSU1 and GLR1) simultaneously in the same cell caused a higher resistance to selenite than overexpression of only one of two genes. Therefore, both genes participate in the selenite detoxification through an additive mechanism. Overexpression of $S S U 1$ was also found to increase the resistance of both wild type strain and $y c f 1$ mutant, while overexpression of $G L R 1$ influenced the sensitivity of only wild type strain, not $y c f 1$. Unexpectedly, the $y c f 1$ mutant was shown to be more resistant to selenite in comparison with the wild type strain. The reason seems to be an active transport of selenodiglutathione into a vacuole in the wild-type cells contrary to the $y c f 1$ mutants, that results in the exhaustion of a pool of reduced glutathione in cytosol, which in its turn causes a less effective reduction of toxic selenite.

As overexpression of glutathione reductase results in a higher sulfite-resistance, it was studied, whether selenite influences the activity of genes, which control the response to the oxidative stress. It was shown that the expression of TRR1 (which codes for cytosol thioredoxin reductase), GLR1, and YCF1 is increased by selenite 14, 4 and 2-fold, respectively, and this process is Yap1p-dependent. Selenite does not influence the activity of SSU1 [15]. Thus, selenite acts to yeast as an active oxidant, inducing genes which defend the cell from oxidative stress (GLR1 and TRR1).

Wine yeast and SSU1. The study of mechanisms of sulfite sensitivity/resistance is being performed also with the usage of wine yeast as a model object. In the course of thousands of years this yeast was under selection to acquire such properties as the ability to ferment must with a high content of sugar quickly and effectively, be resistant to high concentrations of ethanol and sulphur dioxide, and high temperature. Because of this they have unique genetic and biochemical characteristics which differ them considerably from the other yeasts, baker's and brewer's, in particular. Unlike the laboratory strains $S$. cerevisiae, which are haploids or diploids, the wine yeasts are mainly diploids, aneuploids or polyploids, homotallic and highly heterozygous $[63,64]$. They reveal high polymorphism along the chromosomes $[65,66]$ and the increased frequency of the mitotic recombination [67]. It strengthens their ability to reorganize its genome and provides a quick adaptation to the changes of a medium.

Consequently an important question arose about a role of sulfite in the genetic polymorphism of the wine yeast, since it is used as an antibacterial agent at the production of wine. The gene SSU1 was the one being investigated because of its ability to modulate yeast sensitivity to selenite as was stated earlier. It was shown to be expressed much higher in the cells of wine strains as compared with the lab- 
Table 3.

The list of genes which modulate the yeast tolerance to selenium compounds and sulfite.

\begin{tabular}{ll}
\hline \multicolumn{1}{c}{ Genes } & \multicolumn{1}{c}{ Protein function } \\
\hline S. cerevisiae: & \\
MET1 & Uroporphyrinogene-3-methylase \\
MET3 & ATP-sulfurylase \\
MET4 & Regulatory gene \\
MET14 & Adenosine-5'- phosphosulfite kinase \\
MET16 & 3'-phospho-5'-adenylylsulfate \\
MET22 & reductase \\
& Biphosphonucleoside \\
MET28 & phosphohydralase \\
SUL1 & Transcription activator \\
SUL2 & Sulfate transporter \\
SUL3 & Sulfate transporter \\
& Gene SUL2 transcription activator
\end{tabular}

FZF1 (RSU1) Gene SUL1 transcription activator

Sat $^{\mathrm{r}} \mathrm{Chr}^{\mathrm{r}} \mathrm{Met}^{-}$

$\mathrm{Sat}^{\mathrm{r}} \mathrm{Chr}^{\mathrm{r}} \mathrm{Met}^{-}$

46,47

$\mathrm{Sat}^{\mathrm{r}} \mathrm{Chr}^{\mathrm{r}} \mathrm{Met}^{-}$

$\mathrm{Sat}^{\mathrm{r}} \mathrm{Chr}^{\mathrm{r}} \mathrm{Met} \quad 46$

$\mathrm{Sat}^{\mathrm{r}} \mathrm{Chr}^{\mathrm{r}} \mathrm{Met}^{-} \quad 46$

$\mathrm{Sat}^{\mathrm{r}} \mathrm{Chr}^{\mathrm{r}} \mathrm{Met}^{-}$

Sat $^{\mathrm{r}} \mathrm{Chr}^{\mathrm{r}} \mathrm{Met}^{-}$

$\mathrm{Sat}^{\mathrm{r}} \mathrm{Chr}^{\mathrm{r}}$

Sat $^{\mathrm{r}} \mathrm{Chr}^{\mathrm{r}}$

Sat $^{\mathrm{r}}$, Chr ${ }^{\mathrm{r}}$; all mutants are dominant. $\quad 46$

Dominant mutants $\mathrm{Sul}^{\mathrm{r}}$; the increased 51-54 glutathione content, the increased glutathione reductase activity; the decreased quantity of extracellular glutathione; the increased concentration of extracellular acetic aldehyde.

SSU1 Transporter ("sulfate pump"): $\quad$ Recessive mutants: Sul'. The increased expression Takes out sulfite and selenite out of the in wine yeast cells. Amplifying SSU1: $>\mathrm{Sul}^{\mathrm{r}}$, $\operatorname{Sit}^{\mathrm{r}}(3$ cell; $\quad \mathrm{mM}) ;$ ssu $1>$ Sul $^{\mathrm{s}}$.

SSU2 (GRR1) Unknown

$\begin{array}{lll}\text { SSU3 } & \text { Unknown } & \text { S } \\ \text { SSU4 } & \text { Unknown } & \text { S } \\ \text { ECM34 } & \text { Unknown }\end{array}$

Mutant grr 1 pleiotropic Sul ${ }^{\mathrm{s}}$, the change of cell morphology, the increased sensitivity to reducing agents, the decreased excretion of acetic aldehyde, the decreased level of renewed glutathione in cells, the decreased growth on glucose.

$\mathrm{Sul}^{\mathrm{s}}$ 55

$\mathrm{Sul}^{\mathrm{s}}$

Duplication of promoter of this gene and its translocation in SSU1 promoter leads to high expression of the latter and therefore to $\mathrm{Sul}^{\mathrm{r}}$-phenotype.

$\mathrm{Sit}^{\mathrm{r}}$ glutathionreductase 


\begin{tabular}{|c|c|c|c|}
\hline Genes & Protein function & Phenotype/Genotype of mutants & Source \\
\hline YCF1 & $\begin{array}{l}\text { Ycflp - vacuolar protein which performs the } \\
\text { role of pump, besides of cadmium detoxifica- } \\
\text { tion }\end{array}$ & $\mathrm{Sit}^{\mathrm{r}}$ & 15 \\
\hline TRR1 & Cytosolic tioredoxin reductase & $\begin{array}{l}\text { Phenotype is unknown. Selenite de- } \\
\text { presses protein synthesis. }\end{array}$ & 15 \\
\hline$Y A P 1$ & Transcription activator $T R R 1, G L R 1, Y C F 1$ & $\mathrm{Sit}^{\mathrm{s}}$ & 15 \\
\hline $\begin{array}{l}\text { Schizosaccha- } \\
\text { myces pombe: }\end{array}$ & & & \\
\hline $\begin{array}{l}\text { MET3 } \\
\text { Pichia } \\
\text { guilliermondii }\end{array}$ & ATP-sulfurylase & Sat $^{\mathrm{r}}$ & 49,50 \\
\hline SIT1, SIT2 & Unknown & $\mathrm{Sit}^{\mathrm{r}}$ & 16,23 \\
\hline
\end{tabular}

R e m a r k : Phenotype marking: Met ${ }^{-}$- methionine-dependence; $\mathrm{Sat}^{\mathrm{r}}, \mathrm{Chr}^{\mathrm{r}}$, selenate- or chromate-resistance, respectively; Sul ${ }^{\mathrm{s}}$, Sul ${ }^{\mathrm{r}}-$ sensitivity $^{\mathrm{r}}$ resistance to sulfite, respectively; $\mathrm{Sit}^{\mathrm{s}}, \mathrm{Sit}^{\mathrm{r}}-$ sensitivity or resistance to selenite respectively.

oratory ones, besides the increased level of corresponding mRNA correlated with a high tolerance of the strains tested in respect to sulfite [68]. The results of cloning with subsequent sequencing of gene $S S U 1$ showed that a high sulfite resistance of the strains was provided by a new allele of the gene SSU1, called SSU1-R. It arises due to the reciprocal translocation between VIII and XVI chromosomes as a result of unequal crossing-over between microhomologous promoter regions of the genes ECM34 and SSU1, which are located on VIII and XIV chromosomes, respectively. Each of such short sequences of 76 bp (so called "upper activating sequence" - UAS) is the site for binding the transcription activator, namely Fzflp. On the first stage of the reorganization of two chromosomes the amount of $U A S$ in the ECM34 promoter increases by duplication(-s) from one to several, after which as a result of translocation they are relocated within the $S S U 1$ promoter, while the single $U A S$ is remained within the ECM34 promoter. It is noteworthy that the function of the latter is not known yet [69].

First, such reorganization leads to a high polymorphism of two pairs of homologous chromosomes of the corresponding diploid: if before the translocation each of the chromosomes of VIII pair had the length of $562 \mathrm{kbp}$, after the translocation, one of them was extended till 921 $\mathrm{kbp}$. Analogously, after the reorganization, one of the homologous chromosomes of XVI pair had only $599 \mathrm{kbp}$ instead of $948 \mathrm{kbp}$. Second, by means of the described translocation the promoter of the gene SSU1 can contain from 2 to $6 U A S$, due to this the level of expression of the gene SSU1 increases rapidly in the comparison with the wild type strain. A high positive correlation was shown between the amount of $U A S$ and the level of sulfite resistance of the corresponding yeast cell [69].

Non-homologous recombination, described above, is a particularly rare phenomenon in the wild type strains. Its frequency is considered not to exceed $3.5 \times 10^{-10}$. In spite of this all the studied wine strains (more than 10) contain allele $S S U 1-R$ which appears as a result of such extremely rare event, while the wild type strains do not have it $[68$, 69]. Evidently, sulfite in must is one of the important selective factors, in the presence of which the cells with rare mutations of sulfite resistance have an advantage in the growth rate over the parent cells, which contributes to their better survival, and, thus, to the evolution of corresponding strains of wine yeasts in the direction of the sulfite resistance. It should be noted that polymorphism of a certain strain in the length of chromosomes, which appeared as a result of above mentioned translocation, can promote further structural reorganization of chromosomes and, thus, contribute to adaptation of the strain to other unfavourable environmental conditions.

Totally, at present there are revealed 20 genes which modulate the yeast tolerance to selenium compounds and sulfite (Table 3 ). How complete is this list? It is very probable that it will be supplemented by other yet unknown genes. The facts obtained in the study of arsenic influence on yeast support this assumption. Arsenic and selenium 
have a number of similar features, neighbouring in the fourth period of the periodic system of elements. Both are necessary in trace amounts for metabolism and growth as microelements, but they are toxic at higher concentrations. It was shown [70], that the treatment of $S$. cerevisiae cells during 2 hours with $0.1-1.0 \mathrm{mM}$ solution of $\mathrm{NaAsO}_{2}$ had insignificant influence on the growth of the yeast, but the expression of 829 genes out of 6240 studied was changed for a rather long period. Three of them, which activate transcription (MET4, MET28, and YAP1) are induced by selenium as well. Probably, these three factors determine cross-sensitivity/resistance of the cells to both metalloids. One can not also exclude, that selenium itself modulates the expression of not dozens but hundreds of genes which control the yeast tolerance to it.

Therefore, the yeasts acquired certain mechanisms of detoxification in order to survive at non- favorable conditions, due to the presence of selenium oxianions and their analogues, namely:

a control of their transport into and excretion out of the cell;

the oxianions may be reduced inside the cell and metabolized into different forms which are less toxic for the cell (selenium-containing organic compounds, the elemental form of selenium);

compartmentalization (sequestration) of their derivatives in organelles;

complexation with cell metabolites to form less toxic compounds;

oxianions' activated transcription of genes which code for the products protecting the cell at these conditions (antioxidant system).

\section{М. М. Стенчук, Л. Б. Чабан, М. В. Гончар}

Селен і дріжджі. генетичні механізми толерантності дріжджів до сполук селену та їх аналогів

Резюме

Селен (Se) i його сполуки проявляють токсичну і канцерогенну дію на організми людини ітварин, а умалих кількостях він є важливим мікроелементом для живих істот. Тому важливо встановити молекулярні основи токсичності Se та резистентності клітин до нього. Значна кількість досліджень цієї проблеми проведена на бактеріях і висвітлена у ряді оглядів, Можливість використання молекулярно-генетичних методів зробила дріжджі, в основному Sacccharomyces cerevisiae, зручною модельною системою для дослідження механізмів резистентності еукаріотичних клітин до селену на молекулярному рівні. Тому у цьому огляді підсумовано дані, особливо генетичні, про механізми чутливості/резистентності дріжджів до селенових сполук.

Ключові слова: дріжджі, селен, толерантність; yeast, selenium, tolerance.

\section{REFERENCES}

1. Nakamuro K., Okuno T., Hasegawa T. Metabolism of selenoamino acids and contribution of selenium methylation to their toxicity // J. Health Sci.-2000.-Vol. 46, No. 6.-P. 418-421.

2. Lobinski R., Edmonds J.S., Suzuki K.T., Uden P.C. Species-selective determination of selenium compounds in biological materials //Pure Appl. Chem.-2000.-Vol. 72, No. 3.- P. 447-461.

3.Tamas M.J., Wysocki R. Mechanisms involved in metalloid transport and tolerance acquisition //Curr. Genet.-2001.-Vol. 40, No.1.-P. 2-12.

4.[http://www.nsc.org/library/chemical/selenium.htm].

5. Birringer M., Pilawa S., Flohe L. Trends in selenium biochemistry //Nat. Prod. Rep.-2002.-Vol. 19, No.6.-P. 693-718.

6.nSchraucer G.N. Anticarcinogenic effects of selenium //Cell. Mol. Life Sci.- 2000.-Vol. 57, No. 13-14.-P. 1864-1873;

7. Kohrl J., Brigelius-Flohe R., Bock A., Gartner R., Mejer $O$., Flohe L. Selenium in biology: facts and medical perspectives //Biol. Chem.-2000.-Vol. 381, No. 9-10.-P. 849-864.

8. Boles J.O., Cisneros R.J., Weir M.S., Odom J.D., Villafranca J.E., Dunlap R.B. Purification and characterization of selenomethionyl thymidilate synthase from Escherichia coli; comparison with the wild-type enzyme //Biochemistry.-1991.-Vol. 30, No. 46.-P. 11073-11080.

9. Bernard A.R., Wells T.N., Cleasby A., Borlat F., Payton M.A., Proudfoot A.E. Seleenomethionine labeling of phosphomannose isomerase changes its kinetic properties // Eur. J. Biochem.-1995.-Vol. 230, No. 1.-P. 111-118.

10. Huber R.E., Criddle R.S. The isolation and properties of beta-galactosidase from Escherichia coli grown in sodium selenate // Biochim. Biophys. Acta.-1967.-Vol. 141, No.3.-P. 587-599.

11. Ip $C$. Lessons from basic research in selenium and cancer prevention //J. Nutr.-1998.-Vol. 128, No. 11.-P. 1845-1854.

12. Snitynskyi V.V., Antoniuk G.L. Biochemical role of selenium //Ukr. Bioch. Zh.-1994.- Vol. 66, No.5.P. 3-16 (in Ukrainian).

13. Fu L.-H., Wang X.-F., Eyal Y., She Y.-M., Donald L.J., Standing K.G., Ben-Hayyim G. A Selenoprotein in the plant kingdom. Mass spectrometry confirms that an opal codon (UGA) encodes selenocysteine in Chlamidomonas reinhardtii glutathione peroxidase //J. Biol. Chem.-2002.-Vol 277, No. 29.-P. 25983-25991].

14. Golubev V.I., Golubev N.V. Selenium tolerance of yeasts // Mikrobiologiya.-2002.-Vol. 71, No. 4.-P. 455-459. 
15. Pinson B., Sagot I., Daignan-Fornier B. Identification of genes affecting selenite toxicity and resistance in Saccharomyces cerevisiae //Molecular Microbiology.-2000.-Vol. 36, No. 3.-P. 679-687.

16. Chaban L.B., Pokrovetska O.M., Stenchuk M.M., Gonchar M.V. Isolation and physiological characterization of selenite-resistant mutants of the yeast Pichia guilliermondii //Visnyk Lviv Univ. Ser. Biology.-2003. - Is. 34.-P. 92-99 (in Ukrainian).

17. McKeehan W.L., Hamilton W.G., Ham R.G. Selenium is an essential trace nutrient for growth of WI-38 diploid human fibroblasts //Proc. Natl. Acad. Sci. USA.-1976.- Vol. 73, No. 6.-P. 2023-2027.

18. Turner R.J., Weirner J.H., Taylor D.E. Selenium metabolism in Escherichia coli //Biometals.-1998.-Vol. 11, No. 3.-P. 223-227.

19. Kramer G.F., Ames B.N. Mechanisms of mutagenicity and toxicity of sodium selenite $\left(\mathrm{Na}_{2} \mathrm{SeO}_{3}\right)$ in Salmonella typhimurium //Mutant Res.-1988.-Vol. 201, No. 1.-P. 169-180.

20. Reshetnikova I.A., Petrikevich S.B. Lumino-microscopic detection of selenium in the yeast Candida tropicalis //Mikrobiologiya.-1974.-V.43, No. 1.-P. 159-161 (in Russian).

21. Reshetnikova I.A., Petrikevich S.B. Electron microscopic study of the yeast Candida tropicalis grown on a medium containing selenium // Mikrobiologiya.-1975.-Vol. 44, No. 5.-P. 556-558 (in Russian).

22. Charieb M.M., Gadd G.M. Evidence for the involvement of vacuolar activity in metal(loid) tolerance: vacuolar-lacking and -defective mutants of Saccharomyces cerevisiae display higher sensitivity to chromate, tellurite and selenite //Biometals.-1998.Vol.11, No2.-P. 101-106.

23. Chaban L., Stenchuk M., Gonchar M. Genetic analysis of selenite-resistant mutants of the yeast Pichia guilliermondii $/ / 1^{\text {st }}$ Ukrainian Congress for Cell Biology. Lviv, April 25-28, 2004.-Abstract Book.-P. 376.

24. Suhajda A., Hegoczki J., Janzso B., Pais I., Vereczkey $G$. Preparation of selenium yeasts I. Preparation of selenium-enriched Saccharomyces cerevisiae // J. Trace Elem. Med. Biol.- 2000.-Vol. 14, No. 1.- P. 43-47.

25. Ponce de Leon C. A., Bayon M.M., Paquin C, Caruso J.A. Selenium incorporation into Saccharomyces cerevisiae cells: a study of different incorporation methods // J. Appl. Microbiol.- 2002.-Vol. 92, No.4.- P. 602-610.

26. Demirci A., Pometto A.L. III. Production of organically bound selenium yeast by continuous fermentation // J. Agric. Food Chem.-1999.-Vol. 47, No. 6.-P. 2491-2495.

27. Demirci A., Pometto A.L. III, Cox D.J. Enhanced organically bound selenium yeast production by fed-batch fermentation // J. Agric. Food Chem.-1999.-Vol. 47, No. 6.-P 2496-2500.
28. Kotrebai M., Birringer J.F., Tyson J.F., Block E., Uden $P$.C. Selenium speciation in enriched and natural samples by HPLC-ICP-MS and HPLC-MS with perfluorinated carboxylic acid ion-pairing agents //Analyst.-2000.-Vol. 125, No. 1.- P. 71-78.

29. Bansal M.P., Kaur T. Growth characteristic and selenium status changes of yeast cells with inorganic and organic selenium supplementation: selenium, a chemopreventive agent //J. Med. Food.-2002.-Vol. 5, No. 2.-P. 85-90.

30. Yoshida M., Fukunaga K., Tsuchita H., Yasumoto K. An evaluation of the bioavailability of selenium in high-selenium yeast // J. Nutr. Sci. Vitaminol. (Tokyo). -1999.-Vol. 45, No. 1.- P. 119-128.

31. Ortman K, Pehrson B. Selenite and selenium yeast as feed supplements to growing fattening pigs // Zentralbl. Veterinarmed A.-1998.- Vol. 45, No. 9.-P. 551-557.

32. Ortman K., Pehrson B. Selenite and selenium yeast as feed supplements for dairy cows //J. Vet. Med. A.-1997.-Vol. 44, No.6.-P. 373-380.

33. Ortman K., Pehrson B. Effect of selenate as a feed supplement to dairy cows in comparison to selenite and selenium yeast //J. Anim. Sci.-1999.-Vol.77, No. 12.-P. 3365-3370.

34. Knowles S.O., Grace N.D., Wurms K., Lee J. Significance of amount and form of dietary selenium on blood, milk and casein selenium concentration in grazing cows //J. Dairy Sci.-1999.-Vol. 82, No. 2.-P. 429-437.

35. Rock M.J., Kincaid R.L., Carstens G.E. Effects of prenatal source and level of dietary selenium on passive immunity and thermometabolism of newborn lambs //Small Rumin. Res.-2001.-Vol. 40, No. 2.-P. 129-138.

36. Bogye G., Alfthan G., Machay T. Bioavailability of enteral yeast-selenium in preterm infants //Biol. Trace Elem. Res.-1998.-Vol. 65, No. 2.-P. 143-151.

37. Bogye G., Alfthan G., Machay T. Zubovics L. Enteral yeast-selenium supplementation in preterm infants // Arch. Dis. Child Fetal Neonatal Ed.-1998.-Vol. 78, No. 3.-P. 225-226.

38. Seo Y.R., Kelley M.R., Smith M.L. Selenomethionine regulation of p53 by a ref1-dependent redox mechanism //Proc. Natl.. Acad. Sci. USA.-2002.-Vol. 99, No. 22.-P. 14548-14553.

39. Whanger P.D. Selenocompounds in plants and animals and their biological significance $/ / \mathbf{J}$. of the American College of Nutrition.-2002.-Vol. 21, No. 3.-P. 223-232.

40. Lu J., Jiang C., Kaeck M., Ganther H., Vadhanavikit $S$., Ip C., Thompson H. Dissociation of the genotoxic and growth inhibitory effects of selenium //Biochem. Pharmacol.-1995.-Vol. 50, No. 2.-P. 213-219.

41. Sinha R., Said T.K., Medina D. Organic and inorganic selenium compounds inhibit mouse mammary 
cell growth in vitro by different cellular pathways //Cancer Lett.-1996.-Vol. 107,No. 2.-P. 277-284.

42. Alaejos M.S., Diaz Romero F.J., Diaz Romero C. Selenium and cancer: some nutritional aspects // Nutrition.-2000.- Vol. 16, No. 5.-P. 376-383.

43. Rosin M.P. Inhibition of spontaneous mutagenesis in yeast cultures by selenite, selenate and selenide // Cancer Lett.-1981.-Vol. 13, No. 1.-P. 7-14.

44. Anjaria K.B., Madhvanath U. Genotoxicity of selenite in diploid yeast // Mutat. Res.-1988.-Vol. 204, No.4.-P. 605-614.

45. Bronzetti $G$, Cini $M$, Andreoli E, Caltavuturo L, Panunzio M, Croce CD. Protective effects of vitamins and selenium compounds in yeast //Mutat. Res.-2001.-Vol. 496, No 1-2.-P. 105-115.

46. Cherest H., Davidian J.C., Thomas D., Benes V., Ansorge W., Surdin-Kerjan V. Molecular characterization of two high affinity sulfate transporters in Saccharomyces cerevisiae //Genetics.-1997.-Vol. 145, No. 3.- P. 627-635.

47. Breton A., Surdin-Kerjan $V$. Sulfate uptake in Saccharomyces cerevisiae: biochemical and genetic study //J. Bacteriol.-1977. Vol. 132, No. 1.- P. 224-232.

48. Smith F.W., Ealing P.M., Hawkesford M.J., Clarkson D.T. Plant members of a family of sulfate transporters reveal functional subtypes //Proc. Natl. Acad. Sci. USA.-1995..-Vol. 92, No. 20.- P. 9373-9377.

49. Simonics T., Banszky L., Maraz A. Genetics of sulfate assimilation in Schizosaccharomyces pombe (a short review) //Acta Microbiol. Hung.-2002.- Vol. 49, No. 2-3.-P. 279-283.

50. Banszky L., Simonics T., Maraz A. Sulfate metabolism of selenate-resistant Schizosaccharomyces pombe s //J. Gen. Appl. Microbiol.-2003.-Vol. 49, No. 5.-P. 271-278.

51. Casalone E., Colella C.M., Ricci F., Polsinelli M. Isolation and characterization of Saccharomyces cerevisiae mutants resistant to sulfate //Yeast.-1989.-Vol 5, Spec No.-P. 287-291.

52. Casalone E., Colella C.M., Daly S., Gallori E., Moriani L., Polsinelli M. Mechanism of resistance to sulfite in Saccharomyces cerevisiae //Curr. Genet.-1992.-Vol. 22, No. 6-P. 435-440.

53. Casalone E., Colella C.M., Daly S., Fontana S., Torricelli I., Polsinelli M. Cloning and characterization of a sulfit-resisnant gene of Saccharomyces cerevisiae //1994.-Vol. 10, No. 8.-P. 1101-1110.

54. Breitwieser $W$., Price $C$., Schuster T. Identification of a gene encoding a novel zinc finger protein in Saccharomyces cerevisiae //Yeast.-1993.-Vol. 9, No. 5.- P. 551-556.

55. Xu X., Wightman J.D., Geller B.l., Avram D., Bakalinsky A.T. Isolation and characterization of sulfite mutants of Saccharomyces cerevisiae //Curr. Genet.-1994.-Vol. 25, No. 5.- P. 488-496.
56. Avram D., Bakalinsky A.T. FZF1 (SUL1) suppresses the sulfite sensitivity but not the glucose derepression or aberrant cell morphology of a grr1 of Saccharomyces cerevisiae //Genetics.-1996.-Vol. 144, No. 2.- P. 511-521.

57. Park H., Bakalinsky A.T. SSU mediates sulfite efflux in Saccharomyces cerevisiae //Yeast.-2000.-Vol. 16, No 10.-P. 881-888.

58. Park H., Lopez N.I., Bakalinsky A.T. Use of sulfite resistance in Saccharomyces cerevisiae as a dominant selectable marker //Current Genetics.-1999.-Vol. 36, No. 6.-P. 339-344.

59. Sa-Correia I., Tenreiro $S$. The multidrug resistance transporters of the major facilitator superfamily, 6 years after disclosure of Saccharomyces cerevisiae genome sequence //J. Biotechnol.-2002.-Vol. 98, No. 2-3.-P. 215-226.

60. Jelinsky S.A., Samson L.D. Global response of Saccharomyces cerevisiae to an alkylating agent // Proc. Natl. Acad. Sci. USA.-1999.-Vol. 96, No. 4.P. 1486-1491.

61. Flick J.S., Johnston M. GRR1 of Saccharomyces cerevisiae is required for glucose repression and encodes a protein with leucine-rich repeats //Mol. Cell. Biol.-1991.-Vol. 11, No. 10.- P. 5101-5112.

62. Stratford M., Morgan P., Rose A.H. Sulphur dioxide resistance in Saccharomyces cerevisiae and Saccharomycodes ludwigii //J. Gen. Micro.-1987.-Vol.133.-P. 2173-2179.

63. Bakalinsky A.T., Snow R. The chromosomal constitution of wine strains of Saccharomyces cerevisiae //Yeast.-1990.-Vol.6, No.5. -P. 367-382.

64. Codon A.C., Gasent-Ramirez J.M., Benitez T. Factors which affect the frequence of sporulation and tetrad formation in Saccharomyces cerevisiae baker's yeasts //Appl. Environ. Microbiol.-1995.-Vol.61, No. 4.-P. 630-638.

65. Bidenne C., Blondin B., Dequin S., Vezinhet F. Analysis of the chromosomal DNA polymorphism of wine strains of Saccharomyces cerevisiae //Curr. Genet.-1992.-Vol. 22, No. 1.-P. 1-7.

66. Rachidi N., Barre P., Blondin B. Multiple Ty-mediated chromosomal translocations lead to karyotype changes in a wine strain of Saccharomyces cerevisiae //Mol. Gen. Genet.-1999.-Vol. 261, No. 4-5.-P. 841-850.

67. Puig S., Querol A., Barrio E., Perez-Ortin J.E. Mitotic recombination and genetic changes in Saccharomyces cerevisiae during wine fermentation //Appl. Environ. Microbiol.-2000.-Vol. 66, No. 5. -P. 2057-2061.

68. Goto-Yamamoto N., Kitano K., Shiki K., Yoshida Y., Suzuki T., Iwata T., Yamane Y., Hara S. SSU1-R, a sulfite resistance gene of wine yeast, is an allele of SSU1 with a different upstream sequence //J. Ferm. Bioengineer.-1998.-Vol. 56.- No. P. 427-433. 
69. Perez-Ortin J.E., Perez-Ortin J.E., Puig S., Barrio E. Molecular characterization of a chromosomal rearrangement involved in the adaptive evolution of yeast strains //Genome Research.-2002.-Vol. 12, No. 10.-P. 1533-1539.
70. Haugen A.C., Kelley R., Collins J.B., Tucker C.J., Deng C., Afshari C.A., Brown J.M., Ideker T., Van Houten $B$. Integrating phenotypic and expression profiles to map arsenic-response networks //Genome Biol.-2004.-Vol. 5, No. 12.-R95. 